$7-1-2018$

\title{
Trametinib prevents mesothelial-mesenchymal transition and ameliorates abdominal adhesion formation
}

\author{
Edward J. Macarak \\ Thomas Jefferson University \\ Christine Lotto \\ Thomas Jefferson University \\ Deepika Koganti \\ Thomas Jefferson University \\ Xiaoling Jin \\ Thomas Jefferson University
}

Eollow this and additional works at: https://jdc.jefferson.edu/dcbfp Pete J. Wermuth

JPlatis ofetffersembantiversittleommons, and the Surgery Commons

Let us know how access to this document benefits you

See next page for additional authors

Recommended Citation

Macarak, Edward J.; Lotto, Christine; Koganti, Deepika; Jin, Xiaoling; Wermuth, Pete J.; Olsson, Anna-Karin; Montgomery, Matthew; and Rosenbloom, Joel, "Trametinib prevents mesothelialmesenchymal transition and ameliorates abdominal adhesion formation" (2018). Department of Dermatology and Cutaneous Biology Faculty Papers. Paper 92.

https://jdc.jefferson.edu/dcbfp/92

This Article is brought to you for free and open access by the Jefferson Digital Commons. The Jefferson Digital Commons is a service of Thomas Jefferson University's Center for Teaching and Learning (CTL). The Commons is a showcase for Jefferson books and journals, peer-reviewed scholarly publications, unique historical collections from the University archives, and teaching tools. The Jefferson Digital Commons allows researchers and interested readers anywhere in the world to learn about and keep up to date with Jefferson scholarship. This article has been accepted for inclusion in Department of Dermatology and Cutaneous Biology Faculty Papers by an authorized administrator of the Jefferson Digital Commons. For more information, please contact: JeffersonDigitalCommons@jefferson.edu. 


\section{Authors}

Edward J. Macarak, Christine Lotto, Deepika Koganti, Xiaoling Jin, Pete J. Wermuth, Anna-Karin Olsson, Matthew Montgomery, and Joel Rosenbloom 


\title{
Trametinib prevents mesothelial-mesenchymal transition and ameliorates abdominal adhesion formation
}

\author{
Edward J. Macarak, PhD, ${ }^{a, b, *}$ Christine E. Lotto, MD, ${ }^{a, b, c}$ \\ Deepika Koganti, MD, ${ }^{a, b, c}$ Xiaoling Jin, $\mathrm{MD}, \mathrm{PhD},{ }^{a, b}$ \\ Peter J. Wermuth, PhD, ${ }^{a, b}$ Anna-Karin Olsson, MD, ${ }^{d}$ \\ Matthew Montgomery, BS, ${ }^{a, b}$ and Joel Rosenbloom, MD, $\mathrm{PhD}^{a, b}$ \\ ${ }^{a}$ The Joan and Joel Rosenbloom Research Center for Fibrotic Diseases, Sidney Kimmel Medical College, Thomas \\ Jefferson University, Philadelphia, Pennsylvania \\ ${ }^{\mathrm{b}}$ Department of Dermatology and Cutaneous Biology, Sidney Kimmel Medical College, Thomas Jefferson \\ University, Philadelphia, Pennsylvania \\ ${ }^{\mathrm{c}}$ Department of Surgery, Sidney Kimmel Medical College, Thomas Jefferson University, Philadelphia, Pennsylvania \\ ${ }^{\mathrm{d}}$ Department of Medical Biochemistry and Microbiology (IMBIM), Uppsala University, Uppsala, Sweden
}

\section{A R T I C L E I N F O}

Article history:

Received 15 November 2017

Received in revised form

11 January 2018

Accepted 13 February 2018

Available online 20 March 2018

Keywords:

Abdominal adhesions

Anti-fibrotic therapeutics

Trametinib

Mesothelial-mesenchymal

transition

Fibronectin EDA isoform

\section{A B S T R A C T}

Background: Intra-abdominal adhesions are a major cause of morbidity after abdominal or gynecologic surgery. However, knowledge about the pathogenic mechanism(s) is limited, and there are no effective treatments. Here, we investigated a mouse model of bowel adhesion formation and the effect(s) of an Federal Drug Administration-approved drug (trametinib) in preventing adhesion formation.

Materials and methods: C57BL/6 mice were used to develop a consistent model of intra-abdominal adhesion formation by gentle cecal abrasion with mortality rates of $<10 \%$. Adhesion formation was analyzed histologically and immunochemically to characterize the expression of pro-fibrotic marker proteins seen in pathologic scaring and included alpha smooth muscle actin ( $\alpha$ SMA) and fibronectin EDA (FN ${ }^{\mathrm{EDA}}$ ) which arises from alternative splicing of the fibronectin messenger RNA resulting in different protein isoforms. Trichrome staining assessed collagen deposition. Quantitative polymerase chain reaction analysis of RNA isolated from adhesions by laser capture microscopy was carried out to assess pro-fibrotic gene expression. To block adhesion formation, trametinib was administered via a subcutaneous osmotic pump.

Results: Adhesions were seen as early as post-operative day 1 with extensive adhesions being formed and vascularized by day 5 . The expression of the $\mathrm{FN}^{\mathrm{EDA}}$ isoform occurred first with subsequent expression of $\alpha \mathrm{SMA}$ and collagen. The drug trametinib was chosen for in vivo studies because it effectively blocked the mesothelial to mesenchymal transition of rat mesothelium. Trametinib, at the highest dose used $(3 \mathrm{mg} / \mathrm{kg} / \mathrm{d})$, prevented adhesion formation while at lower doses, adhesions were usually limited, as evidenced by the presence of $\mathrm{FN}^{\mathrm{EDA}}$ isoform but not $\alpha \mathrm{SMA}$.

\footnotetext{
* Corresponding author. Department of Dermatology and Cutaneous Biology, Thomas Jefferson University, 233 South $10^{\text {th }}$ Street, Philadelphia, PA 19107. Tel.: +1 (215) 573 5775; fax: +1 (215) 5035788.

E-mail address: Edward.Macarak@Jefferson.edu (E.J. Macarak). 0022-4804/\$ - see front matter @ 2018 The Authors. Published by Elsevier Inc. This is an open access article under the CC BY-NC-ND license (http://creativecommons.org/licenses/by-nc-nd/4.0/). 
Conclusions: Cecal abrasion in mice is a reliable model to study abdominal adhesions, which can be ameliorated using the MEK1/2 inhibitor trametinib. While blocking adhesion formation at the cell and molecular levels, trametinib, at the therapeutic doses utilized, did not impair the wound healing at the laparotomy site.

(c) 2018 The Authors. Published by Elsevier Inc. This is an open access article under the CC BY-NC-ND license (http://creativecommons.org/licenses/by-nc-nd/4.0/).

\section{Introduction}

Although peritoneal adhesions may be caused by infection, inflammation, or ischemia, surgical procedures are the primary cause since greater than $90 \%$ of patients will develop adhesions after abdominal surgery. ${ }^{1}$ In the United States between 1998 and 2002, over 18\% of hospital admissions were secondary to abdominal adhesions alone resulting in approximately $948,000 \mathrm{~d}$ of inpatient hospital care at an estimated cost of 1.18 billion dollars. ${ }^{2}$ Such adhesions are responsible for pelvic pain, bowel obstruction, and infertility. Although modern advances in surgical technique, including laparoscopy, have led to a decrease in their incidence, intestinal adhesions still pose a very significant medical as well as economic problem. ${ }^{3,4}$ Unfortunately, adequate therapeutic solutions have proven elusive. While there are some studies using therapeutics to attempt to prevent adhesion formation, these have largely not gained wide acceptance. ${ }^{5-10}$ Similarly, the use of barriers has also produced mixed results. ${ }^{11}$ Once formed, adhesions are removed by adhesiolysis surgery. More recent studies have shown that adhesiolysis procedures in the United States account for 967,332 d of care at a cost of 2.3 billion dollars. ${ }^{12}$

Adhesion formation has a complex pathogenesis and can be broken down into several stages which are as follows.

(1) An inflammatory response, whose blockage has largely proven to be unsuccessful. It is characterized by an influx of multiple cell types and production of a variety of cytokines and factors. ${ }^{13,14}$

(2) The coagulation cascade and clot formation whose characterization is critical to understand adhesion pathogenesis. Multiple studies provide a rational basis for enhancing clot lysis as a therapeutic strategy. However, in practice, this has proven difficult. These events occur early postoperatively, and the failure of fibrinolysis allows cellular infiltration of the initial fibrinous matrix. ${ }^{15-18}$ Although, in many cases, the formation of a clot is essential to limit injury, resolution of the clot, in a timely manner, is necessary to prevent adhesion formation. Thus, the balance between fibrin clot formation and its lysis is critical.

(3) The final stage in the adhesion process is formation of a connective tissue scar. By and large, this stage causes the most severe complications and has many common features with fibrotic reactions found elsewhere in the body, including systemic ones (e.g., scleroderma) and those affecting individual organs including lung, heart, liver, and kidney.

Because the pathophysiology of fibrotic reactions has received insufficient attention, there exists an urgent need for cellular and molecular characterization of adhesion formation. The critical cell in the formation of an adhesion is the myofibroblast which produces increased amounts of fibrillar collagens as well as other matrix proteins and which expresses alpha smooth muscle actin ( $\alpha \mathrm{SMA}$ ), a molecular marker of activated myofibroblasts. ${ }^{19,20}$ Although the origins of myofibroblasts may differ depending on the affected organ and the initiating event, in the abdominal cavity, they may arise through a process of trans-differentiation of mesothelial cells in which these cells lose their specific epithelial phenotypic markers such as expression of E-cadherin and acquire a mesenchymal or myofibroblast phenotype. This change in mesothelial phenotype has been termed mesothelial-mesenchymal transition (MMT).

Since its first identification, it has been known that transforming growth factor- $\beta$ (TGF- $\beta$ ), a pleiotropic growth factor with a wide and diverse spectrum of biological activities, plays a key role in fibrotic diseases by mediating the formation of myofibroblasts and stimulating the production of extracellular matrix (ECM, $\left.{ }^{21-24}\right)$. In addition to TGF- $\beta$, interleukin- 6 , another pleiotropic cytokine with a diverse range of biological activities, ${ }^{25-27}$ was also found to be elevated in peritoneal fluid during and/or after abdominal surgeries thus potentially implicating it in the cascade of events which lead to adhesion formation. ${ }^{28}$ Significantly, the levels of these cytokines correlated with the severity of abdominal adhesion formation. ${ }^{29,30}$ The complex signaling pathways activated by TGF- $\beta$ involve both canonical and noncanonical signaling pathways. In the present context, the critical downstream event elicited by noncanonical signaling is the mitogen activated protein kinase (MEK) activation of Erk1/2, which, when activated by phosphorylation, enters the nucleus and, in association with other factors, mediate the transcription of pro-fibrotic genes and cell cycle regulatory proteins (Fig. $1,{ }^{31}$ ).

We have previously found that U0126, a MEK1/2 inhibitor not in clinical use, blocked the rat peritoneal MMT induced by TGF- $\beta{ }^{32}$ To extend these findings to a drug with clinical potential, in the present study we have evaluated the effect of the MEK1/2 inhibitor, trametinib, currently in clinical use in the treatment of malignant melanoma in humans, on the TGF- $\beta$-induced rat peritoneal MMT and abdominal adhesion formation in a mouse model. Trametinib effectively blocked the MMT in vitro and markedly diminished adhesion formation in vivo, likely by inhibiting the activation of Erk1/2. ${ }^{32}$ Taken together, these findings indicate that trametinib may be a useful drug for the inhibition of adhesion formation and warrant human clinical studies.

The goals of the present study were to use the mouse cecal abrasion model to characterize the temporal pro-fibrotic 


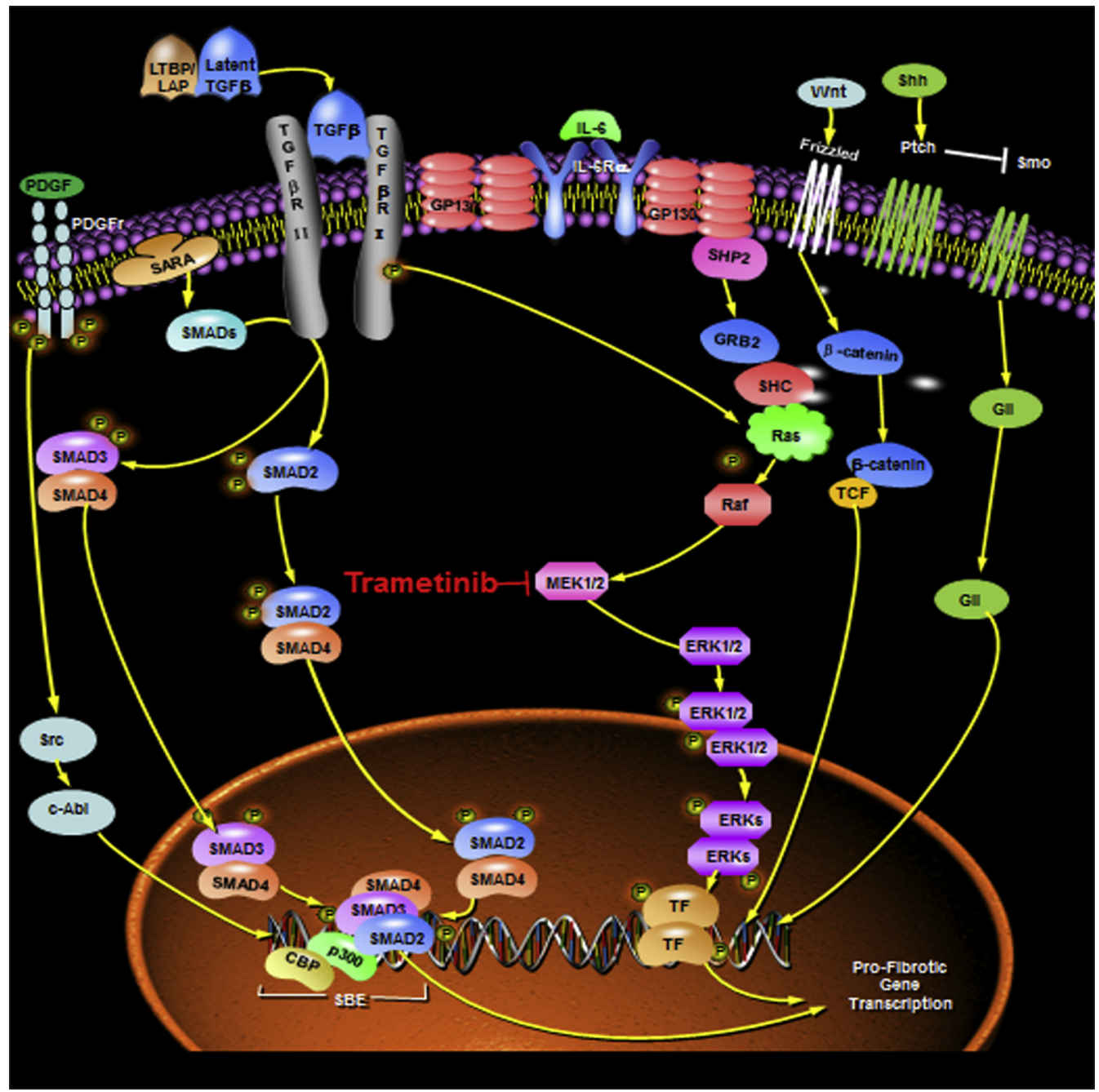

Fig. 1 - TGF- $\beta$ and interleukin- 6 pathways leading to activation of MEK1/2 and Erk1/2 and their inhibition by trametinib. Both TGF- $\beta$ and interleukin- 6 have been shown to activate a "downstream" common signaling pathway through Ras, which results in the activation of Erk1/2. Erk1/2 has many potential downstream activities, but only their role(s) as transcriptions factors is illustrated. Although the relevant pathways have been simplified for clarity, the figure shows the most important elements in the present context. TGF- $\beta=$ transforming growth factor- $\beta$; LAP = latency associated peptide, GP = glycoprotein; SARA = SMAD anchor for receptor activation; SMAD = SMA and MAD related family of signal transducers; CBP = CREB binding protein; TF = transcription factor; SHC = SHC transforming protein, an adapter protein that couples growth factor receptors to signaling pathways; GRB = growth factor receptor bound protein. (Color version of figure is available online.) This figure has been modified from two produced by ProteinLounge.

cellular and molecular events that occur during adhesion formation and determine whether the drug trametinib, a MEK1/2 inhibitor, can block and/or alter these events.

\section{Materials and methods}

Reagents and antibodies

All reagents, unless otherwise specified, were purchased from Sigma (St. Louis, MO). Polyvinylidene difluoride membrane was purchased from Roche Diagnostics, Basel, Switzerland. Antibodies to: Phospho-MEK1/2 (Ser217/221) \#9154, Phospho-Smad2 (Ser465/467) \#3108, Phospho-Smad2
(Ser245/250/255) \#3104, Phospho-p44/42 MAPK (Erk1/2) (Thr202/Tyr204)\#4370 were purchased from Cell Signaling Technology, Danvers, MA. Antibody to the EDA isoform of rat fibronectin ( $\mathrm{FN}^{\mathrm{EDA}}$ ) was developed and characterized by one of us, ${ }^{33}$ and $\alpha$ SMA \#ab5694 was purchased from Abcam, Cambridge, MA. Trametinib was purchased from LC Laboratories, Woburn, MA.

Isolation and culture of rat peritoneal mesothelial cells

The experiments in this study were approved by the Institutional Animal Care and Use Committee at Thomas Jefferson University and were performed in accordance with the National Institutes of Health guidelines for the care and 
handling of laboratory animals. Rat peritoneal mesothelial cells (RPMCs) were isolated and cultured as described previously. ${ }^{34}$ Briefly, Sprague Dawley rats weighing $150 \mathrm{~g}-250 \mathrm{~g}$, purchased from Jackson Laboratory, were injected intraperitoneally with $30 \mathrm{~mL}$ of $0.25 \%$ trypsin/2.21 mM EDTA under isoflurane anesthesia and were kept on the metal pad warmed to $37^{\circ} \mathrm{C}$ for $1 \mathrm{~h}$ after which the abdominal fluid was collected and centrifuged at $300 \mathrm{~g}$ for $10 \mathrm{~min}$. The pelleted cells were resuspended and cultured in DMEM/F12 medium (ThermoFisher Scientific, Philadelphia, PA) supplemented with $10 \%(\mathrm{v} / \mathrm{v})$ fetal bovine serum (ThermoFisher Scientific) at $37^{\circ} \mathrm{C}$ in a humidified atmosphere of $5 \% \mathrm{CO}_{2}$ in air. The RPMCs, from the fourth to seventh passages (split ratio 1:4), at $90 \%$ confluence were used for the experiments. The cells were treated either with $10 \mathrm{ng} / \mathrm{mL}$ of TGF- $\beta 1$ (R\&D systems, Minneapolis, MN) alone or with TGF- $\beta 1$ and the MEK1/2 inhibitor, trametinib (2 or $5 \mathrm{nM}$ ).

\section{Cecal abrasion model}

Equal numbers of male and female C57BL/6 mice (18-25g, 8-10 wk of age, Jackson Laboratories, Bar Harbor, Maine) were used in initial experiments while only male mice were used in the drug escalation studies because they sustained greater accumulations of fibrotic tissue (data not shown). Mice were allowed to acclimate in the animal facility for at least $1 \mathrm{wk}$ before surgery, given free access to standard chow and water, and a 12-h light-dark cycle in standard acrylic cages with wood chip bedding. Animals were randomly assigned into either an experimental group (laparotomy and cecal abrasion) or a control group (laparotomy only).

Briefly, mice underwent induction and maintenance anesthesia with $1 \%-3 \%$ isoflurane with supplemental oxygen. After adequate sedation was achieved, mice were weighed, and $0.1 \mathrm{mg} / \mathrm{kg}$ subcutaneous Buprenex (Hospira, Inc, Lake Forest, IL) was administered to ensure analgesia. The ventral surface was clipped along the midline, and the skin was sterilized with betadine solution. A $2 \mathrm{~cm}$ midline incision was made sub-xyphoid to avoid injuring the bladder, and the cecum was identified and externalized. The anti-mesenteric side of the cecum was gently swiped 30 times with gauze and then returned to the abdomen. We found that 30 swipes were sufficient to promote the formation of petechial hemorrhagic regions and presumably inflict damage to the mesothelial layer of the cecum. The incision was closed with a double layer of sutures with 2-0 silk. ${ }^{35}$ To characterize adhesion formation temporally, mice were divided into groups, each with six males and six females which were necropsied at 1, 2, 5, 8, 11, 14, 17, 21, and $23 \mathrm{~d}$ post-surgery. Each time point also contained two male mice and one female mouse as controls. In the drug escalation study, laparotomy and cecal abrasion were carried out as above as well as subdermal placement of the osmotic pumps in the back of the mice.

\section{Drug treatment with trametinib}

Animals were treated with three different doses of the drug trametinib dissolved in dimethyl sulfoxide (DMSO) in a dose escalation study. Groups of five animals were given $0.1,1.0$, or $3.0 \mathrm{mg} / \mathrm{kg}$ animal weight of drug/d via osmotic pumps (Alzet Osmotic Pump 1002, Cupertino, CA) for 8 d before sacrifice. The volume delivered/d was $6 \mu$ l of drug. Control mice underwent induction with anesthesia and laparotomy only. In addition, five animals underwent laparotomy and placement of the osmotic pumps which were filled with "drug vehicle" (DMSO) alone, that is, no drug. After $8 \mathrm{~d}$ of drug or vehicle treatment, mice were euthanized by $\mathrm{CO}_{2}$ asphyxiation followed by cervical dislocation. The entire large intestine and cecum were removed and partitioned for histology and immunofluorescence microscopy. Adhesions were examined by 2 independent practitioners.

\section{Histology}

Bowel and abdominal wall involved in the adhesion were removed en bloc and fixed in $4 \%$ buffered formalin. Bowel from nondrug-treated mice was also taken as a control. Tissues were dehydrated, embedded in paraffin, and sectioned at either 5 or 10 microns $(\mu)$. Sections were deparaffinized in a graded ethanol series and stained with Masson's trichrome stain. Three complete bowel segments (5 for 3-mg dosed mice) for each drug dose (0.1, 1.0, and $3.0 \mathrm{mg} /$ $\mathrm{kg} / \mathrm{d}$ ) were serially sectioned and all regions where bowel segments were either close to one another or touching were photographed using phase microscopy, and selected sections were then subsequently stained with trichrome and/or processed for immunohistochemistry. Photographs were taken with a Zeiss light microscope equipped with a Nikon digital camera.

Table 1 - Primers employed for semi-quantitative real-time PCR

\begin{tabular}{lcc} 
Gene & Forward primer $\left(5^{\prime}-3^{\prime}\right)$ & Reverse primer $\left(5^{\prime}-3^{\prime}\right)$ \\
\hline 18S & ACCAGAGCGGAAAGCATTTGCCA & TCGGCATCGTTTATGGTCGGAA \\
Col1a1 & GCATGGCCAAGAAGACATCG & TCCACGTCTCAGCATTGGG \\
Col3a1 & AGCTTTGTGCAAAGTGGAACCTGG & CAAGGTGGCTGCATCCCAATTCAT \\
Fn1 & TCCAGGACAACAGCATCAGTGTCA & CCACAGTGGGTTGCAAACCTTCAA \\
Fn- ${ }^{\text {EDA }}$ & TAAAGGACTGGCATTCACTGA & GTGCAAGGCAACCACACTGAC \\
$\alpha$-SMA & GACTCTCTTCCAGCCATCTTTC & GACAGGACGTTGTTAGCATAGA \\
\hline
\end{tabular}

Col1a1 = collagen type 1 alpha chain; Col3a1 = collagen type III alpha chain; Fn- ${ }^{\text {EDA }}=$ fibronectin splicing isoform EDA; Fn1 = plasma fibronectin; $\alpha$-Sma $=\alpha$-smooth muscle actin. 
A
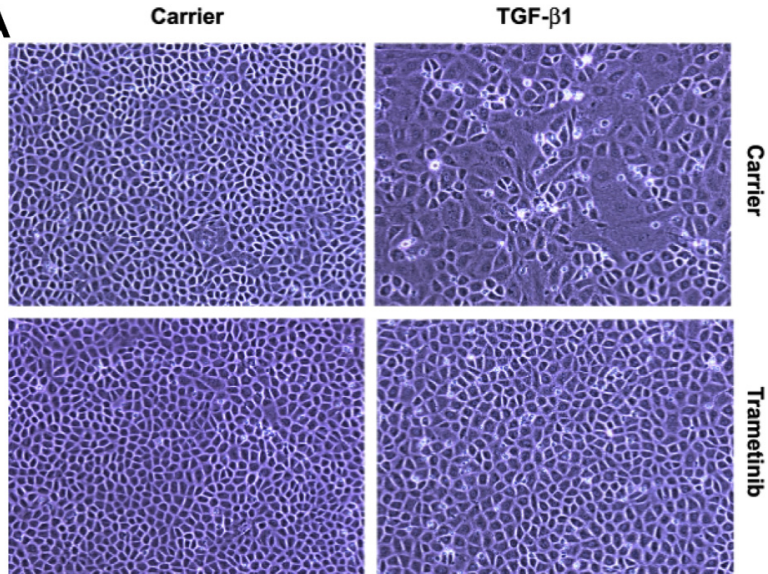

B

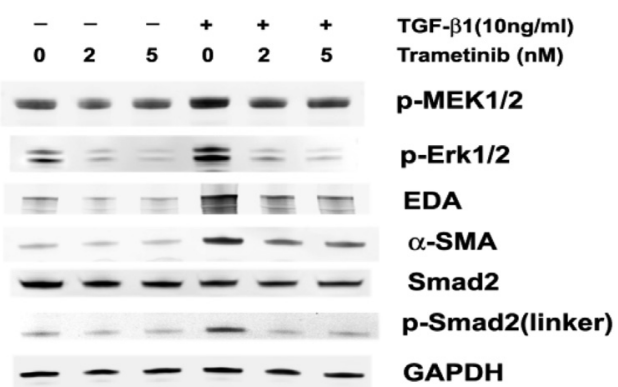

Fig. 2 - (A) Cultured rat peritoneal mesothelial cells treated either with TGF- $\beta$ alone or plus trametinib. Cells treated with TGF- $\beta$ alone (upper right panel) show cells transitioning to a fibroblast-like morphology while cells treated with TGF- $\beta$ + trametinib (5 nM) show no such morphologic changes (lower right panel). (B) Western analysis of proteins isolated from rat peritoneal mesothelial cells treated with and without TGF $\beta$ and with and without trametinib. Note that $p-E r k 1 / 2$ shows a dramatic reduction after stimulation with TGF $\beta 1$ in the presence of either 2 or $5 \mathrm{nM}$ trametinib as do $\mathrm{FN}^{\mathrm{EDA}}, \alpha \mathrm{SMA}$, and the $\mathrm{p}-\mathrm{Smad} 2$ (linker region). TGF- $\beta=$ transforming growth factor- $\beta$; $\propto$ SMA = alpha smooth muscle actin; FN $^{\text {EDA }}=$ fibronectin EDA; GAPDH = glyceraldehyde 3phosphate dehydrogenase. (Color version of figure is available online.)

\section{Immunofluorescence microscopy}

Bowel tissue was placed in Tissue-Tek O.C.T. Compound (Sakura Finetek, Torrance, CA) and immediately frozen in liquid nitrogen. Frozen sections were cut at either 5 or $10 \mu$, allowed to adhere to albumin-coated slides and then washed with phosphate buffered saline (PBS), followed by double staining with goat anti- $\alpha$ SMA polyclonal antibody (1:100), and anti-Fn ${ }^{\mathrm{EDA}}$ antibody (1:75) after prior fixation in cold $\left(4^{\circ} \mathrm{C}\right.$ methanol) overnight at $4^{\circ} \mathrm{C}$. After washing $3 \mathrm{X}$ with PBS, species-matched Alexa-Fluor secondary antibodies (Invitrogen, Carlsbad, CA) were added and incubated for $1 \mathrm{~h}$ at room temperature followed by three washes with PBS. Slides were mounted with 4',6-diamidino-2-phenylindole (DAPI) Fluoromount-G (Southern Biotech, Birmingham, AL), and fluorescence images were taken either with a Zeiss

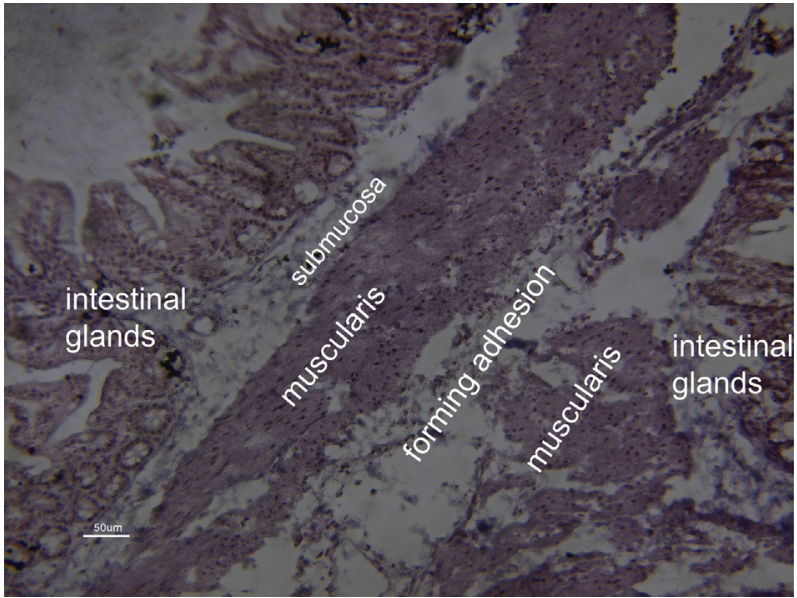

Fig. 3 - Trichrome-section through adjacent intestinal loops showing a forming adhesion on day 1 post-surgery. The forming adhesion consists of a loose granular tissue with little organized structure. (Color version of figure is available online.)

epifluorescence microscope ( $5 \mu$ sections) or a Nikon confocal microscope (10 $\mu$ sections). Controls included: (1) omitting the primary antibody and replacing it either with saline or indifferent IgG from a control animal and (2) omission of the secondary antibody. In all instances, controls were either negative or showed very slight nonspecific staining with the secondary antibody alone (Fig. 7B).

\section{RNA isolation and real-time PCR}

Tissue from selected adhesions was isolated by laser capture microscopy affixed to membranes which were placed in lysis buffer using a protocol provided by the instrument manufacturer (Arcturus, ThermoFisher Scientific). Subsequently, RNA was isolated using the RNeasy Mini Kit (Qiagen, Valencia, CA). Isolated RNA was reverse transcribed using All-in-One cDNA Synthesis SuperMix (Bimake, Houston, TX) to generate first-strand complementary DNA. Transcript levels of pro-fibrotic genes associated with fibrosis and myofibroblast differentiation were determined using SYBR Green real-time PCR as previously described. ${ }^{36,37}$ Primers were designed using Primer Quest (Integrated DNA Technologies, Skokie, Illinois) and were validated for specificity. The sequences of the primers employed are shown in Table 1. The differences in the number of mRNA copies in each PCR were corrected for $18 \mathrm{~S}$ RNA endogenous control transcript levels; expression levels in day 5 mice were set at $100 \%$, and all other values were expressed as normalized multiples of these values.

\section{Western blotting analysis}

RPMCs were lysed in ice-cold modified RIPA buffer with protease inhibitor cocktail $(50 \mathrm{mM} / \mathrm{L}$ Tris- $\mathrm{HCl}, 1 \% \mathrm{NP}-40$, $0.25 \%$ sodium deoxycholate, $150 \mathrm{mM} / \mathrm{L} \mathrm{NaCl}, 1 \mathrm{mM} / \mathrm{L}$ EDTA, $1 \mathrm{mM} / \mathrm{L}$ phenylmethyl sulfonyl fluoride, $1 \mathrm{mM} / \mathrm{L}$ sodium orthovanadate, $1 \mathrm{mM} / \mathrm{L}$ sodium fluoride, $\mathrm{pH}$ 7.4). Equivalent 


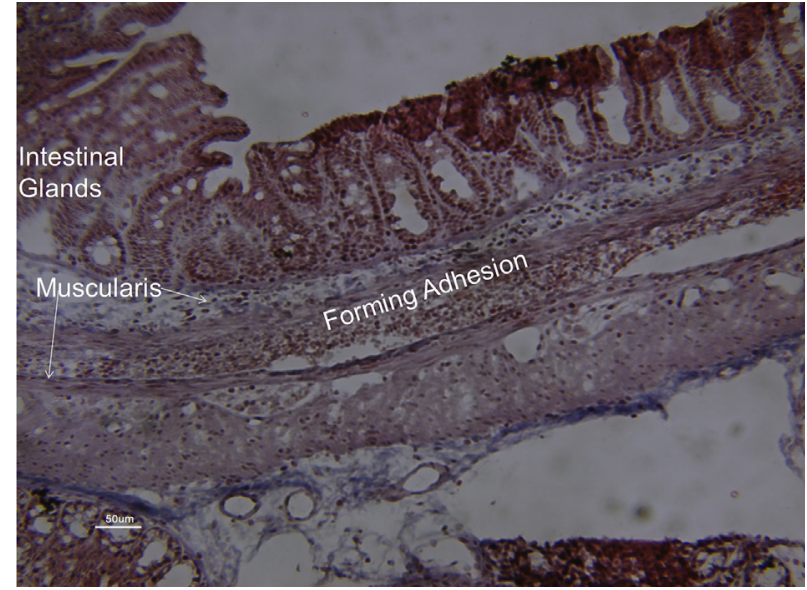

Fig. 4 - Trichrome-stained section through adjacent intestinal loops showing a forming adhesion on day 2 post-surgery. The forming adhesion is becoming more cellular, vascular, and substantial. (Color version of figure is available online.)

amounts of homogenate $(50 \mu \mathrm{g} /$ well), determined by Coomassie blue assay, were separated by sodium dodecyl sulfate polyacrylamide gel electrophoresis, transferred to either nitrocellulose or polyvinylidene difluoride membranes, and detected by either SuperSignal West Femto or SuperSignal West Pico chemiluminescence substrate (ThermoFisher Scientific).

\section{Results}

Effect of trametinib on mesothelial/mesenchymal transition

Isolated mesothelial cells were incubated under control conditions without either TGF- $\beta$ or trametinib, with TGF- $\beta$ or trametinib alone, or with both TGF- $\beta$ and trametinib for $5 \mathrm{~d}$ (Fig. 2A). We have previously found that this length of time was required for maximal mesothelial/mesenchymal transitional effect of TGF- $\beta$ on these rat cells. ${ }^{32}$ As before, TGF- $\beta$ produced a dramatic transitional effect (upper right panel), markedly altering the appearance of the cells from their normal morphology (upper left panel), whereas trametinib alone had no effect and no apparent toxic effects with the cells maintaining a cobblestone appearance (lower left panel). Remarkably, trametinib blocked the effect of TGF- $\beta$, and the cells retained their epithelial morphology (lower right panel).

Based on our early observations (data not shown), TGF$\beta$-treated cells gained $\alpha$ SMA and COL1A1 expression, which was prevented by treatment with $5 \mathrm{nM}$ trametinib. These insights led us to explore the potential mechanisms of action of trametinib using Western blotting analyses (Fig. 2B). These experiments demonstrated that TGF- $\beta$ produced a substantial increase in the phosphorylation/activation of Erk1/2 and phosphorylation of the Smad2 linker region ${ }^{38}$ as well as increases in expression of $\alpha \mathrm{SMA}$ and $\mathrm{FN}^{\mathrm{EDA}}$. These increases in the expression of $\mathrm{p}$-Erk1/2, FN ${ }^{\mathrm{EDA}}, \alpha \mathrm{SMA}$, and $\mathrm{p}$-SMAD2 (linker) were blocked by as low a concentration of trametinib as $2 \mathrm{nM}$ (Fig. 2B).

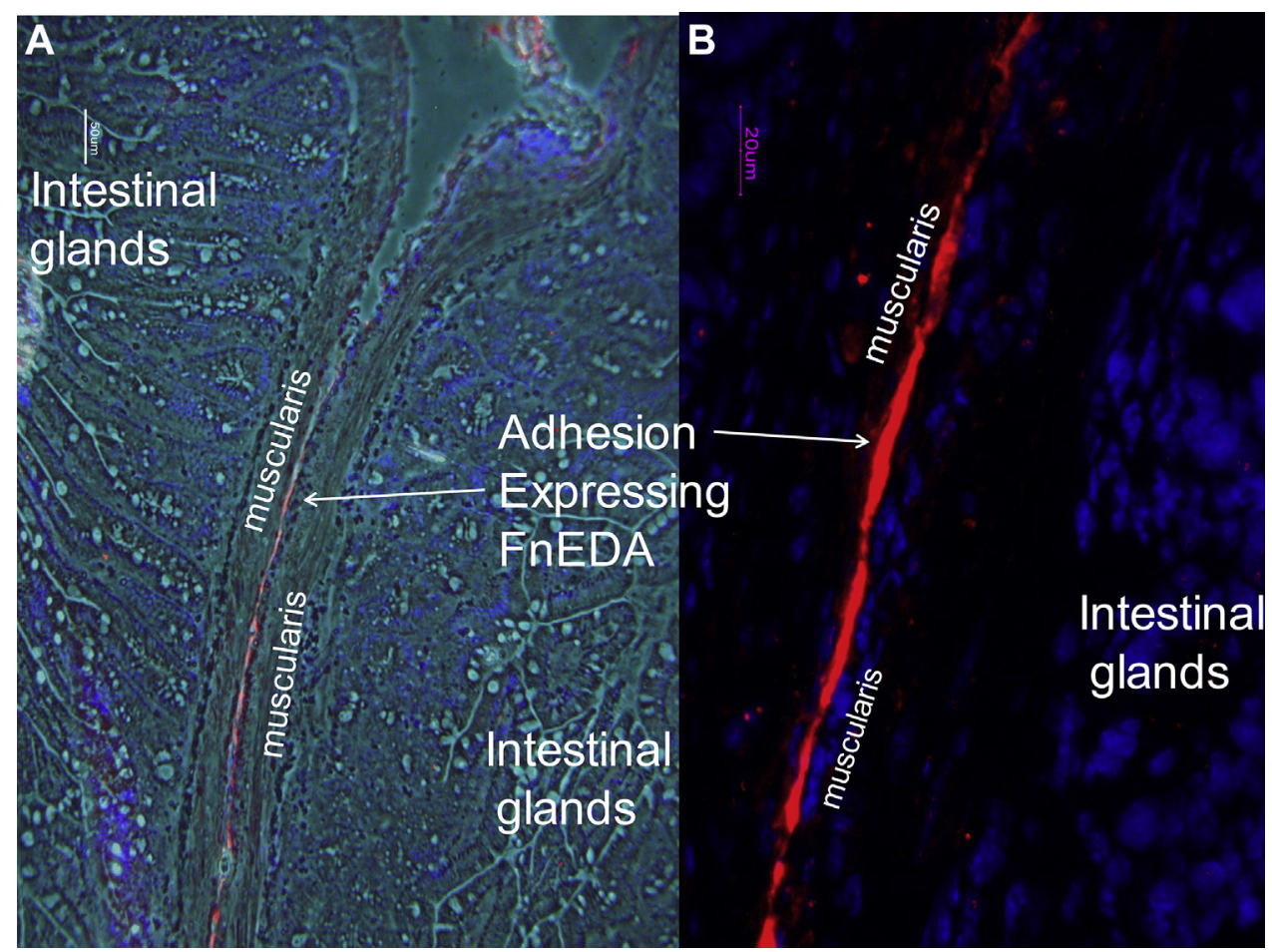

Fig. 5 - Section through adjacent intestinal loops stained with an antibody to FN ${ }^{\mathrm{EDA}}$ showing a forming adhesion at day 2 post-surgery. (A) Combined phase-immunofluorescence photograph showing the localization of the FN ${ }^{\mathrm{EDA}}$ antibody (arrows) within the forming adhesion $(\times 100)$. (B) Photograph of the same area as (A) but taken at a higher magnification $(\times 400) . \mathrm{FN}^{\mathrm{EDA}}=$ fibronectin EDA. (Color version of figure is available online.) 


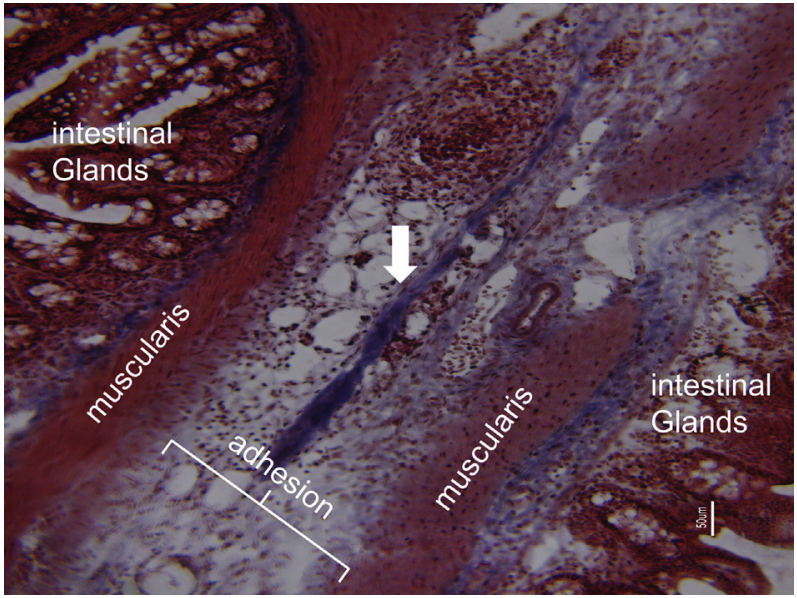

Fig. 6 - Trichrome-stained section through adjacent intestinal loops showing a forming adhesion on day 5 post-surgery. Highly cellular and well-formed adhesion with both arterial and venous structures. Note the central blue staining region (arrow) within the adhesion indicating the presence of collagen. (Color version of figure is available online.)

Characterization of adhesion formation in the mouse model

To characterize adhesion formation in the mouse model, mice sacrificed at post-surgery time points after cecal abrasion were examined by both trichrome staining and immunohistochemistry using antibodies raised against pro-fibrotic proteins. The histology of the large intestine of the mouse is similar to that of humans and consists of a lining of columnar epithelium containing many goblet cells. The epithelium surrounding the lumen is underlain by a somewhat poorly characterized myofibroblast layer embedded in the lamina propria and surrounded by a submucosa and two layers of muscularis (an inner circular and an outer longitudinal layer) covered with a thin layer of mesothelium.

The first appearance of adhesions was seen as early as day 1 with the appearance of loose granulation tissue between adjacent intestinal loops and/or the cecum (Fig. 3). The development of the adhesion proceeds during day 2 with increasing cellularity and vascularity within the developing adhesion (Fig. 4). In addition, there is the appearance of $\mathrm{FN}^{\mathrm{EDA}}$ on day 2, which first is deposited in the small space between the closely apposed bowel loops (Fig. 5A). Figure 5B is an immunofluorescent image from the same region as shown in Figure 5A but at a greater magnification; it clearly shows that $\mathrm{Fn}^{\mathrm{EDA}}$ is initially deposited as the adhesion is in its formative stage in the region between the adjacent intestinal loops. Between day 2 and day 5 after surgery, the adhesion develops rapidly with greater cellularity as well as vascularization of the newly generated adhesion as shown in Figure 6. The adhesion is a well-formed entity with many blood vessels including arterioles and venules and the presence of a collagen-containing ECM (blue trichrome staining, arrow). Thus, the day 5 adhesions appear robust with well-formed blood vessels in an organized matrix containing type I collagen and $\mathrm{Fn}^{\mathrm{EDA}}$. Initially, type III collagen is also present (data not shown). Interestingly, at day 5 post-surgery, cells

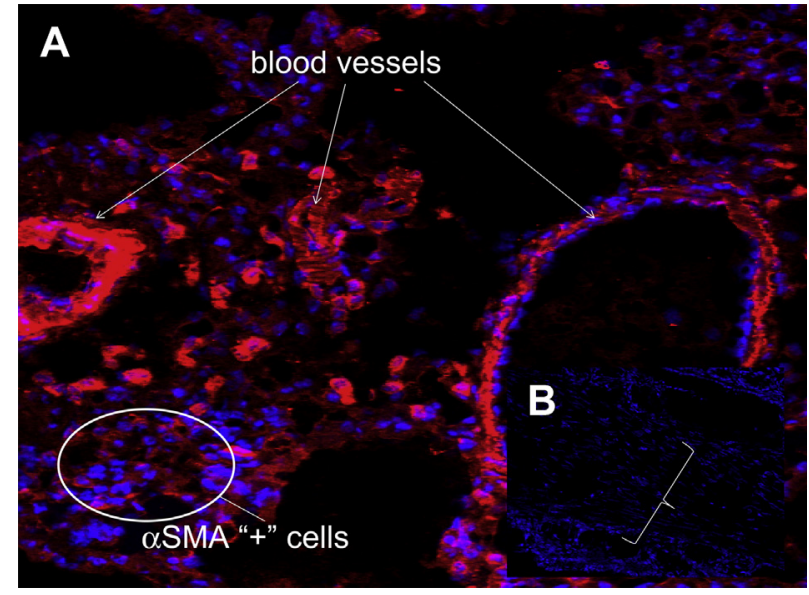

Fig. 7 - Confocal immunofluorescent photograph showing localization of antibody to $\alpha$ SMA within a forming adhesion on day 5 post-surgery. ( $\alpha$ SMA $=$ red, DAPI nuclear stain = blue). (A) Note the abundant localization of antibody to $\alpha$ SMA to cells within the adhesion indicating the presence of myofibroblasts within the adhesion. There is also localization of the antibody to the smooth muscle cells associated with the tunica media of blood vessels within the same area which serves as a "positive" control for the antibody (arrows). $\times 100$. (B) Control photograph of region between two intestinal loops showing adhesion area (bracket) incubated with two secondary antibodies alone (no primaries) and DAPI nuclear stain showing no specific localization. Bracket indicates region of adhesion. $\times 100 . \alpha S M A=$ alpha smooth muscle actin. Arrows point to artery on left, small arterioles in center and large vein on right. (Color version of figure is available online.)

that localize antibody to $\alpha$ SMA are present as shown in Figure 7. In the same figure, the antibody to $\alpha$ SMA also localized extensively to smooth muscle of multiple small and large blood vessels whose staining serve as an internal control for antibody specificity. The small inset in Figure 6 is a control stained with DAPI but without antibody to aSMA. Adhesions that are present at day 8-23 post-surgery illustrate a continued maturation of the adhesions, which become highly cellular and vascular. By day 20, the adhesion is robust and highly cellular with many well-developed blood vessels (Fig. 8).

To quantify the progressive connective tissue changes in adhesions temporally, measurements of pixel density were carried using a Nikon A1R confocal microscope. Images of tissues stained with antibody to type I collagen were collected from three different mouse samples for each time point. Multiple adhesions from each of three 5 day and three 8-day post-surgery adhesions were analyzed using Image $J$ image analysis of confocal photographs. For photographs used for the quantification of collagen, the camera settings were unchanged for all photographs taken with the digital camera. As shown in Table 2, there is a highly statistically significant increase $\left(P=1.6 \times 10^{-4}\right)$ in the level of type I collagen found in adhesions at $8 \mathrm{~d}$ postsurgery versus those at $5 \mathrm{~d}$.

To determine if differences in gene expression were associated with the histologic and immunohistochemical changes observed, laser capture dissection of the adhesive tissue was 


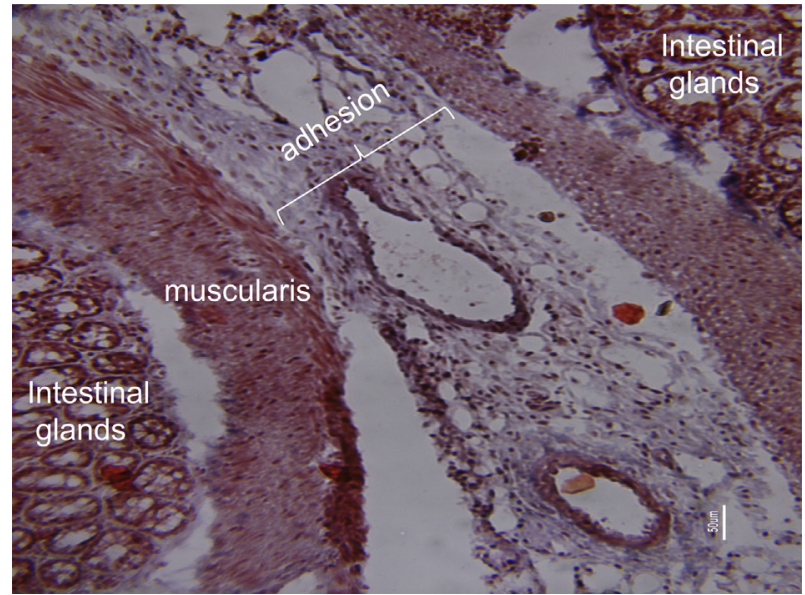

Fig. 8 - Trichrome-stained section through adjacent intestinal loops showing a mature adhesion on day 20 post-surgery. This region illustrates a well-formed mature adhesion with a highly vascularized structure within a collagenous extracellular matrix. The adhesion has an abundance of cells, many of which are likely myofibroblasts based upon their localization of antibody to $\alpha$ SMA at day 5 as shown above in Fig. 7 B. $\times 100 . \alpha$ SMA $=$ alpha smooth muscle actin. (Color version of figure is available online.)

carried out. Adhesions were identified and boundaries of the adhesions defined by the staining of the muscularis externa with phalloidin (Fig. 9). Tissue between adjacent bowel loops was captured and subjected to RNA isolation and quantitative polymerase chain reaction ( $\mathrm{qPCR}$ ) quantification as described in the Methods. These data, which are shown in Figure 9 and which show an approximately four fold increase in type I collagen gene expression, corroborate measurements of type I collagen pixel density (Table 2). Thus, immunohistochemistry and qPCR both show increased expression of type I collagen between day 5 and day 8. In addition, qPCR measurements also showed increased expression for type III collagen ( seven fold increase), plasma Fn ( $\sim 5$ - fold increase), $\alpha$ SMA ( five fold increase), and $\mathrm{Fn}^{\mathrm{EDA}}$ ( $\sim 10$-fold increase). Interestingly, of the pro-fibrotic genes measured, the largest overall increase was that of $\mathrm{Fn}^{\mathrm{EDA}}$ (Fig. 10).

\section{Trametinib drug treatment}

To evaluate the effect(s) of the drug trametinib on adhesion formation, a series of experiments were carried out in which mice were treated with three different concentrations of

Table 2 - Mean gray values of adhesions at day 5 and 8 postsurgery.

\begin{tabular}{lcc} 
Time point & Mean gray value & Standard deviation \\
\hline Day 5 & 658.10 & 277.67 \\
Day 8 & 1008.30 & 461.49 \\
\% Increase: & 53 & \\
Student t-test & $P=1.6 \times 10^{-4}$ & \\
\hline
\end{tabular}

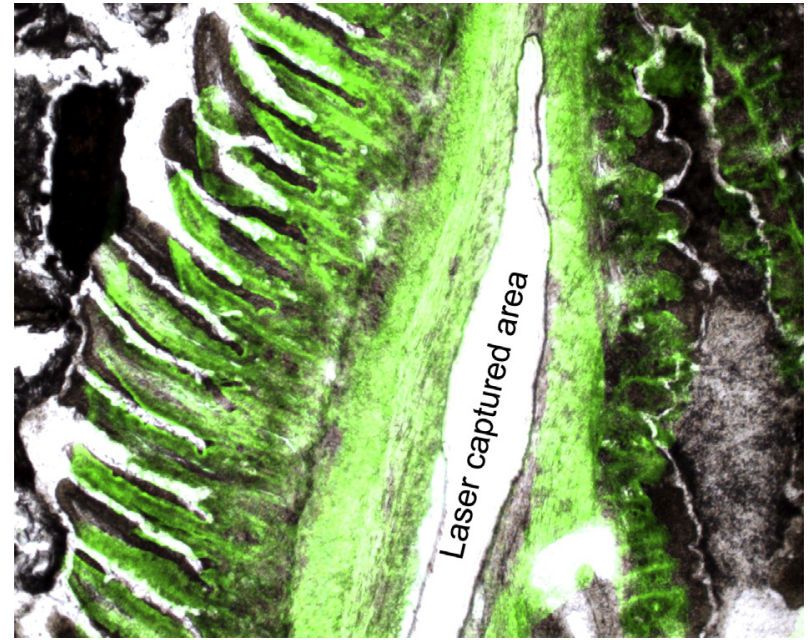

Fig. 9 - Laser capture image of tissue selected for qPCR. Representative tissue sections from 5 to $8 \mathrm{~d}$ pro-fibrotic mice were cut at $\mathbf{1 5}$ microns and adhered to Arcturus microslides. Adhesion areas were identified after prior staining of the sections with phalloidin. These areas were marked for laser dissection and collected according to the Arcturus protocols in Qiagen RLT lysis buffer for subsequent RNA extraction. (Color version of figure is available online.)

trametinib over an 8-day period. Animals appeared to tolerate the drug with no adverse events noted (changes in behavior, eating, weight loss). Changes in average weight within each dosage group over the $8 \mathrm{~d}$ period of drug delivery were unremarkable: $1.0 \mathrm{mg}$ dose - $2.2 \%$ average decrease in weight, $3.0 \mathrm{mg}$ dose: $0.5 \%$ average increase in weight. As well, there appears to be no effect on wound closure and healing (Fig. 11). The surgical site shown is representative of the animals receiving the highest drug dose $(3 \mathrm{mg} / \mathrm{kg} / \mathrm{d})$. In most of the animals, the wound was essentially healed by $8 \mathrm{~d}$ post-surgery. Since the drug is minimally soluble in water, DMSO was used as a "vehicle" to solubilize it. To investigate the possibility that the DMSO itself may induce side effects, an additional series of five animals were subjected to the same surgeries as the mice receiving drug, that is, laparotomies and sub-dermal osmotic pump placement; however, for these additional animals, the pumps contained DMSO but no drug. Analysis of these animals demonstrated that the DMSO neither had any effect on survivability nor wound healing. Thus, although these animals developed abdominal adhesions, they showed no discernible consequences of the treatment with DMSO (data not shown).

In Figure 12A, the adhesion between adjacent bowel loops of a day 8 post-surgery mouse treated with trametinib $(0.1 \mathrm{mg} / \mathrm{kg} / \mathrm{d})$ show cells largely localizing antibody to $\mathrm{Fn}^{\mathrm{EDA}}$ in the center of the adhesion. There does not appear to be any cells which localize antibody to $\alpha$ SMA. In Figure $12 B$, the adhesion, also treated with $0.1 \mathrm{mg} / \mathrm{kg} / \mathrm{d}$ of trametinib, appears to be a more advanced adhesion than that shown in Figure 12A since there are more myofibroblast cells localizing antibody to $\alpha$ SMA. Nevertheless, few cells (arrows) localize antibody to $\alpha \mathrm{SMA}$ suggesting the presence of a modest 


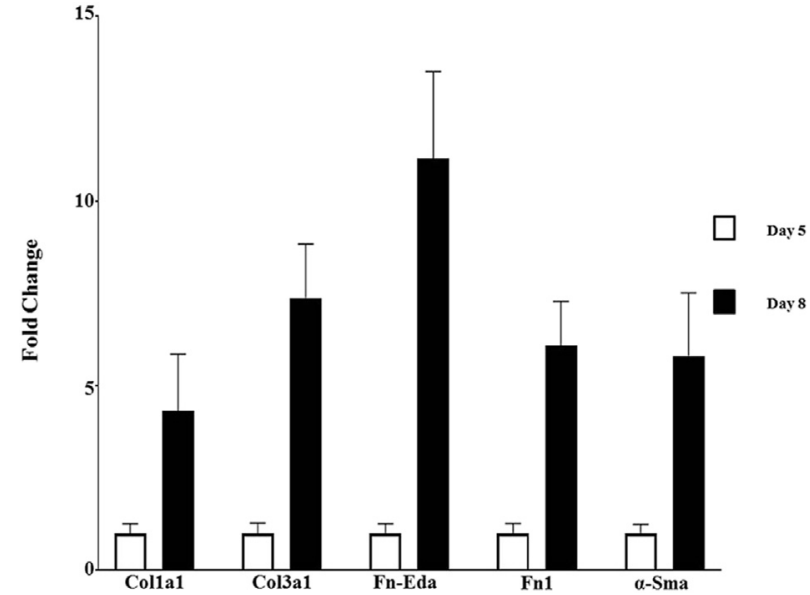

Fig. 10 - qPCR of laser-captured tissue from 5 to $8 \mathrm{~d}$ adhesions. Transcript levels of pro-fibrotic genes were quantified using SYBR Green real-time PCR. ${ }^{39,40}$ Primers were designed using Primer Quest (Integrated DNA Technologies) and were validated for specificity (Table 1). The differences in the number of mRNA copies in each PCR were normalized for 18S RNA endogenous control transcript levels. In the figure, expression levels in control mice were set at $100 \%$, and all other values were expressed as normalized multiples of these values. Day 5 values were set to 1 . Col1a1 = collagen type 1 alpha chain;

Col3a1 = collagen type III alpha chain; Fn-

Eda = fibronectin splicing isoform EDA; Fn1 = plasma

fibronectin; and $\alpha$-Sma $=\alpha$-smooth muscle actin. All data were reported as the mean ( \pm standard error of the mean) of at least three separate animals. Statistical analysis was performed using a t-test, and the level of significance was set at $P<0.05$ or less.

number of myofibroblasts. This adhesion is much less welldeveloped than that shown in Figure 5 despite the presence of vascular structures present (arrows) and a weakly developed ECM. The abraded cecum reacts to the physical damage by producing $\mathrm{Fn}^{\mathrm{EDA}}$.

Figure 13 shows closely adjacent intestinal loops from different animals treated with $3 \mathrm{mg} / \mathrm{kg} / \mathrm{d}$ of trametinib. The space between the loops is clearly defined but shows no sign of a developed adhesion (bracket). The examples shown in this figure are typical of all the bowel sections taken from animals receiving the highest drug dose. Although there were regions where intestinal loops were close to one another, as shown in Figure 13, no adhesions were observed in these regions.

\section{Discussion}

We have used a mouse model of cecal abrasion to initiate the formation of abdominal adhesions. Adhesion formation begins almost immediately after surgery and adhesion sites show evidence of the presence of myofibroblasts within $5 d$, as demonstrated by cells expressing $\alpha \mathrm{SMA}$ and $\mathrm{Fn}^{\mathrm{EDA}}$ within the developing adhesion. We did not address the origin of the myofibroblasts because it is beyond the scope of this study; however, our in vitro experiments with RPMCs suggest the

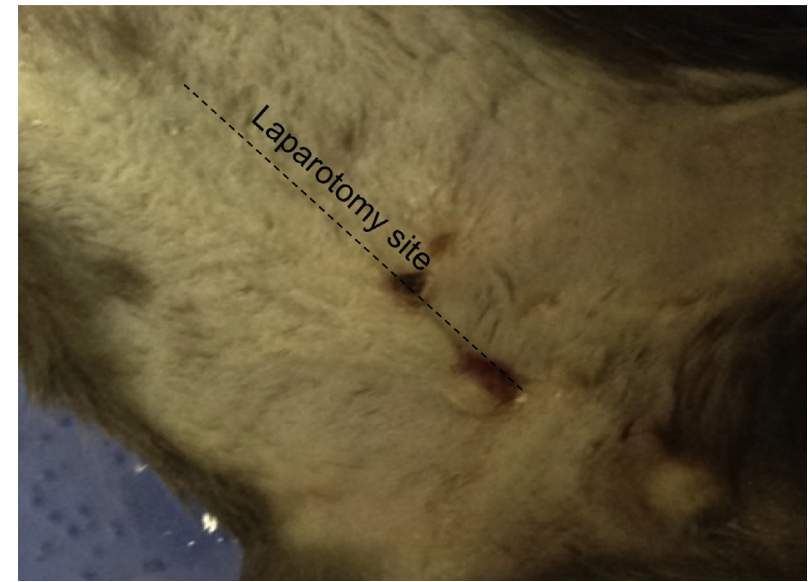

Fig. 11 - Photograph of the abdomen of a mouse treated with the highest dose of trametinib. The laparotomy site (dotted line) has almost completely healed by $8 \mathrm{~d}$ post-surgery. In some animals, there was complete closure of the incision by $8 \mathrm{~d}$. (Color version of figure is available online.)

possible contribution of mesothelial cells to the pathophysiology of adhesion formation.

Myofibroblasts, associated with fibrotic reactions, may arise from different sources depending on the affected organ and the initiating event including: (1) activation of tissue resident fibroblasts in response to specific signals from infiltrating inflammatory cells ${ }^{36}$; (2) recruitment of bone marrow precursor cells known as fibrocytes which express bone marrow cellular surface markers such as CD34 but are capable of ECM production ${ }^{36,37}$; and (3) trans-differentiation of epithelial, mesothelial, and endothelial cells into activated myofibroblasts. Although this process was originally described in epithelial cells and designated epithelial to mesenchymal transition, it is now known that very similar processes occur in the case of mesothelial (MMT) and endothelial (EndoMT) cells. ${ }^{41-43}$

In these transitions, the epithelial, mesothelial, or endothelial cells lose their cell type-specific markers and phenotypic traits, such as expression of E-cadherin and acquire a mesenchymal or myofibroblast phenotype, ultimately initiating the expression of $\alpha$ SMA and vimentin and ECM proteins including $\mathrm{Fn}^{\mathrm{EDA}}$. The expression of these proteins is consistent with a transition of the mesothelial cells to myofibroblasts. ${ }^{43,44}$ Similarly, our immunofluorescence data in the mouse model at $2 \mathrm{~d}$ post-surgery show the presence of $\mathrm{Fn}^{\mathrm{EDA}}$ within the adhesions suggesting that these $\mathrm{Fn}^{\mathrm{EDA}}$ positive cells either have or are transitioning into a contractile myofibroblast.

Cells which are Fn EDA "positive" and $\alpha$ SMA "negative" are considered proto-myofibroblasts, and it is only later after the proto-myofibroblasts express $\alpha$ SMA that they are termed myofibroblasts. Thus, the presence of contractile myofibroblasts is a hallmark of fibrotic tissue whose maturation is preceded by the expression of $\mathrm{Fn}^{\mathrm{EDA}} .{ }^{20}$ The fact that some cells within the adhesion, shown in Figure $11 \mathrm{~A}$, express only $\mathrm{Fn}^{\mathrm{EDA}}$ and not aSMA (compare Fig. 12A and B) suggests that trametinib may interfere with the conversion of the precursor proto-myofibroblast into a myofibroblast. A functional consequence of this may be the inability of the proto-myofibroblast to contract since 

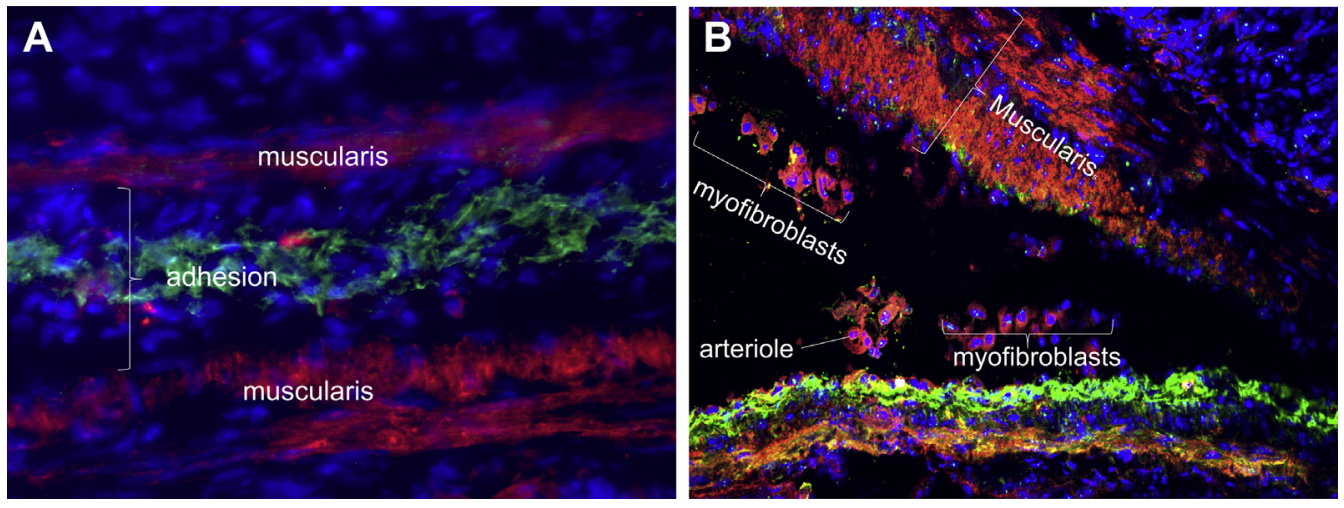

Fig. 12 - Immunofluorescence confocal photographs of two adhesions at day 8 post-surgery from mice treated with $0.1 \mathrm{mg} / \mathrm{kg} / \mathrm{d}$ of trametinib ( $\mathrm{Fn}^{\mathrm{EDA}}=$ green, $\alpha \mathrm{SMA}=$ red, DAPI nuclear stain = blue, $\mathrm{M}=$ muscularis). (A) Antibody to $\mathrm{FN}^{\mathrm{EDA}}$ is prominently localized to the adhesion center while only a few cells localize antibody to $\alpha$ SMA $\times 200$. (B) Extensive localization of antibody to $\alpha$ SMA to the smooth muscle cells of the muscularis externa is shown. In addition, note the localization of $\alpha$ SMA to many myofibroblasts and blood vessels within the adhesions. $\times 200 . \alpha$ SMA $=$ alpha smooth muscle actin; FN ${ }^{\mathrm{EDA}}=$ fibronectin EDA. (Color version of figure is available online.)

both $\alpha \mathrm{SMA}$ and $\mathrm{Fn}{ }^{\mathrm{EDA}}$ are required to mediate the transfer of intracellular force to the ECM. ${ }^{44}$ It has been demonstrated that myofibroblast contraction activates latent TGF- $\beta 1$ releasing it from the ECM, which initiates the pro-fibrotic cascade of events. ${ }^{45,46}$

Figures 7A and 12B show adhesions in control mice and those dosed with $0.1 \mathrm{mg} / \mathrm{kg} / \mathrm{d}$ of trametinib and clearly show an abundance of $\alpha \mathrm{SMA}$-positive cells. Presumably, these are the cells producing the collagen that accumulates within the

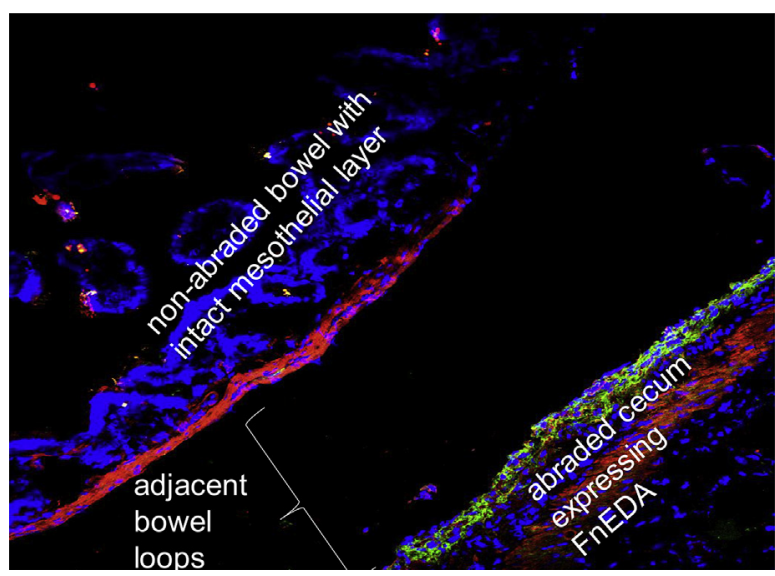

Fig. 13 - Immunofluorescence confocal photograph of a section through adjacent intestinal loops showing a potential adhesion (bracket) in mice treated with $0.1 \mathrm{mg} /$ $\mathrm{kg} / \mathrm{d}$ of trametinib on day 8 post-surgery $\left(\mathrm{Fn}^{\mathrm{EDA}}=\right.$ green, $\alpha$ SMA $=$ red, DAPI nuclear stain $=$ blue). Note that the region between the cecum and the bowel segment (a presumptive adhesion, bracket) is devoid of cells localizing antibody neither to $\mathrm{Fn}^{\mathrm{EDA}}$ nor $\alpha \mathrm{SMA}$ and that only the cecum is expressing $\mathrm{Fn}^{\mathrm{EDA}}$ as a result of the abrasion technique. The opposite bowel loop has intact mesothelial nuclei and likely represents uninvolved bowel. $\times 200$. aSMA = alpha smooth muscle actin; FN $^{\mathrm{EDA}}=$ fibronectin EDA. (Color version of figure is available online.) adhesion as demonstrated not only by histologic and immunohistochemical methods but also by pixel intensity quantification of confocal images and qPCR (Table 2 and Fig. 10). It is important to note that the occurrence of adhesions in the drug-treated animals given the highest dose of trametinib $(3 \mathrm{mg} / \mathrm{kg} / \mathrm{d})$ must be an extremely rare event if it occurs at all. In the five animals whose bowels were serially sectioned, we observed regions where the cecum and intestinal loops were in close proximity to one another but without development of a discernible adhesion (Fig. 14). When such regions were found in the trametinib-treated animals ( 0.1 and $1.0 \mathrm{mg} / \mathrm{kg} / \mathrm{d}$ dose levels), lesion development appeared to be inversely proportional to the level of drug administered. For example, fairly extensive lesions were found at the lowest dose while mice administered the $1 \mathrm{mg} / \mathrm{kg} / \mathrm{d}$ had adhesions which were poorly formed and which appeared to have low levels of aSMA "positive" cells. These data support the view that adhesions in mice treated with the middle dose of trametinib $(1 \mathrm{mg} / \mathrm{kg} / \mathrm{d})$ had limited complete trans-differentiation of cells into myofibroblasts, which we and others define as a cell expressing both $\alpha \mathrm{SMA}$ and $\mathrm{FN}^{\mathrm{EDA}}$. ${ }^{20,47,48}$ This diminution of myofibroblast presence is in contrast to that found either in untreated animals or in animals receiving the lowest dose (Fig. 12B). This suggests that trametinib may be active in ameliorating and/or blocking the early stages of adhesion formation, something which may be useful in preventing formation in humans.

The localization of FN ${ }^{\mathrm{EDA}}$ (Figs. 5 and 12A) occurred in the central region either between the cecum and bowel loops or associated with the surface of the abraded cecum. These central regions quickly became highly cellular and vascularized. Our in vitro studies with rat mesothelial cells show that after stimulation with TGF- $\beta$, they undergo MMT and begin expressing both $\alpha \mathrm{SMA}$ and $\mathrm{Fn}^{\mathrm{EDA}}$ and that U0126, a Mek1/2 inhibitor, was very effective in blocking their MMT. ${ }^{32}$ Practically, mesothelial cells are reasonable candidates to trans-differentiate into myofibroblasts as others have suggested. ${ }^{49,50}$ However, much additional work will need to be carried out to validate this possibility because it is also 


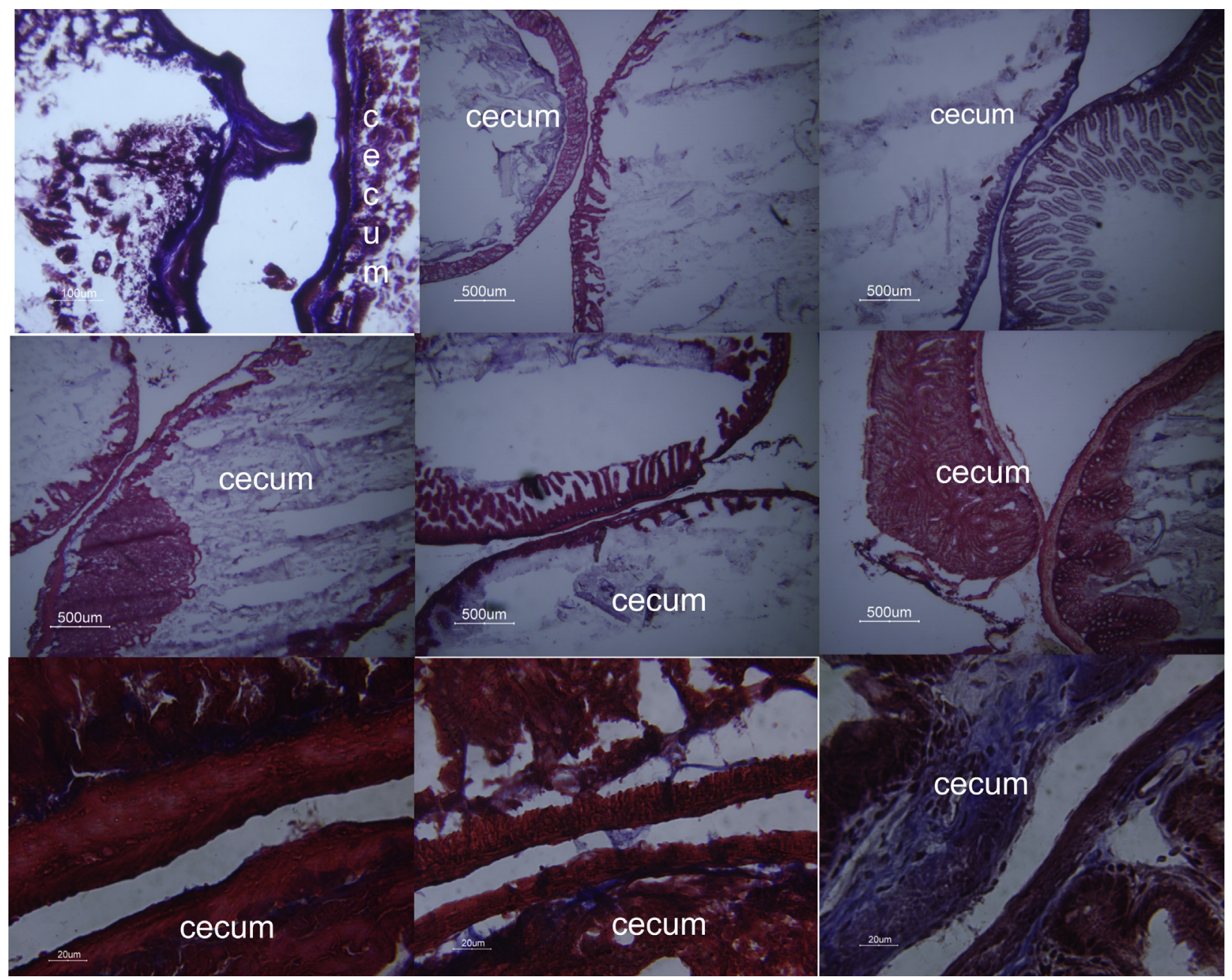

Fig. 14 - Group of trichrome-stained sections through adjacent intestinal loops on day 8 post-surgery mice treated with $3 \mathrm{mg} / \mathrm{kg} / \mathrm{d}$ of trametinib. Mice treated with the highest dose of trametinib $(3.0 \mathrm{mg} / \mathrm{kg} / \mathrm{d})$ essentially developed no adhesions. Although there are many potential adhesion regions where the intestinal loops with intact epithelium muscularis layers are close together, (as shown here), none of these areas developed adhesions (evidenced by the lack of granulation tissue) similar to those observed either in control animals or animals which received lower doses of trametinib. (Color version of figure is available online.)

possible that the myofibroblasts may originate from other sources as well. ${ }^{51-53}$ Interestingly, qPCR data of RNA isolated from adhesions by laser capture microscopy at day 5 and 8 postsurgery show the expression of $\mathrm{Fn}^{\mathrm{EDA}}$, $\alpha \mathrm{SMA}$, and collagen increased significantly raising the possibility that MMT may occur in vivo.

In our current investigation, these previous in vitro studies using U01126 were duplicated using trametinib on RPMCs with similar results to those found at both the morphologic and molecular levels. In the presence of trametinib, the characteristic cobblestone appearance of normal mesothelial cells was maintained (Fig. 2), the expression of $\mathrm{Fn}^{\mathrm{EDA}}$ and $\alpha$ SMA was inhibited, and the phosphorylation of Erk1/2 was essentially blocked completely (Fig. 2B). Interestingly, the concentrations of trametinib used in the present experiments were considerably lower ( 2 or $5 \mathrm{nM}$ ) than that used in experiments involving cultured melanoma cells $\left(100 \mathrm{nM},{ }^{54}\right)$. This suggests that a positive therapeutic response with trametinib could be attained at a much lower dose in fibrotic reactions than that required for tumor responses in vivo, minimizing any potential toxic events of the drug.

Significantly, during adhesion formation in the mouse model, there was a rapid formation of blood vessels within the adhesion. Since surgery may disrupt blood flow, a consequence is that the tissue becomes hypoxic which is accelerated by the rapid influx of highly metabolic inflammatory cells participating in the wound healing process. These cells initiate the formation of granulation tissue and promote the trans-differentiations and proliferation of the myofibroblasts. For example, fibroblasts can be induced to secrete increased amounts of TGF- $\beta$ under hypoxic conditions thus contributing to the overall pro-fibrotic process during wound healing. ${ }^{55}$ The role of hypoxia has been further corroborated by studies in rats which demonstrated that hyperbaric oxygen can reduce the pro-fibrotic changes associated with intra-abdominal adhesions ${ }^{56}$ presumably by increasing $\mathrm{PO}_{2}$ tissue levels.

The present findings demonstrate that trametinib can effectively inhibit adhesion formation in a mouse model that 
mimics potential human clinical situations. Since previous treatments have met with limited success, new therapeutic approaches are necessary and additional clinical testing of trametinib will be required to validate its use in humans. Most importantly with respect to its therapeutic use in humans, our observations also demonstrate that the effective dosage(s) of trametinib used had no adverse effect on the healing of the surgical wound required to access the abdominal cavity in the mouse model. At necropsy $8 \mathrm{~d}$ post-surgery both the abdominal musculature and the overlying skin had largely healed. This demonstrates that trametinib, at least in the mouse model, did not impede wound healing.

In summary, these data suggest that abdominal adhesion formation appears to be the result of common pathophysiologic mechanisms operative in other fibrotic reactions mediated, at least in part, by the phosphorylation of Erk1/2. Activation of these signaling pathways results in formation of an ECM containing collagen ${ }^{57}$ and $\mathrm{FN}^{\mathrm{EDA}}$ in resident cells. ${ }^{58}$

\section{Conclusions}

1. Cecal abrasion is a reliable model for generation of intraabdominal adhesions.

2. Trametinib, a MEK1/2 inhibitor, ameliorated adhesion formation with little or no effect on wound healing at the laparotomy site in mice.

3. Adhesions quickly become populated by myofibroblasts as the adhesions matured which did not occur in mice treated with $3 \mathrm{mg} / \mathrm{kg} / \mathrm{d}$ of trametinib.

4. This model may be of great use to test the effects of other therapeutic agents on abdominal adhesion formation.

\section{Acknowledgment}

Authors' contributions: E.J.M., C.E.L., X.J., D.K., P.J.W., and J.R. contributed for study conception and design; E.J.M., C.E.L., X.J., D.K., P.J.W., A-K.O., and M.M. contributed for acquisition of data; E.J.M., C.E.L., X.J., D.K., P.J.W., A-K.O., M.M., and J.R. contributed for analysis and interpretation of data; E.J.M. D.K., P.J.W., A-K.O., and J.R. drafted the manuscript; E.J.M. C.E.L., X.J., D.K., P.J.W., A-K.O., M.M., and J.R. critically revised the article.

\section{Disclosure}

E.J.M. and J.R. and Thomas Jefferson University have applied for a "use" patent for the drug trametinib in blocking adhesion formation. All other authors report no proprietary or commercial interest in any product mentioned or concept disclosed in this article.

\section{R E F E R E N C E S}

1. Ray NF, Denton WG, Thamer M, Henderson SC, Perry S. Abdominal adhesiolysis: inpatient care and expenditures in the United States in 1994. J Am Coll Surg. 1998;186:1-9.
2. Ward BC, Panitch A. Abdominal adhesions: current and novel therapies. J Surg Res. 2011;165:91-111.

3. Diamond MP. Reduction of postoperative adhesion development. Fertil Steril. 2016;106:994-997.e991.

4. Moris D, Chakedis J, Rahnemai-Azar AA, et al. Postoperative abdominal adhesions: clinical significance and advances in prevention and management. J Gastrointest Surg. 2017;21:1713-1722.

5. Rodgers KE, Girgis W, St Amand K, Campeau JD, diZerega GS. Reduction of adhesion formation by intraperitoneal administration of various anti-inflammatory agents. J Invest Surg. 1998;11:327-339.

6. Guvenal T, Cetin A, Ozdemir H, Yanar O, Kaya T. Prevention of postoperative adhesion formation in rat uterine horn model by nimesulide: a selective COX-2 inhibitor. Hum Reprod. 2001;16:1732-1735.

7. Arung W, Jehaes F, Cheramy JP, et al. Effects of parecoxib on the prevention of postoperative peritoneal adhesions in rats. J Invest Surg. 2013;26:340-346.

8. Arung W, Meurisse M, Detry O. Pathophysiology and prevention of postoperative peritoneal adhesions. World $J$ Gastroenterol. 2011;17:4545-4553.

9. Javaherzadeh M, Shekarchizadeh A, Kafaei M, Mirafshrieh A, Mosaffa N, Sabet B. Effects of intraperitoneal administration of Simvastatin in prevention of postoperative intraabdominal adhesion formation in animal model of rat. Bull Emerg Trauma. 2016;4:156-160.

10. Hong GS, Schwandt T, Stein K, et al. Effects of macrophagedependent peroxisome proliferator-activated receptor gamma signalling on adhesion formation after abdominal surgery in an experimental model. Br J Surg. 2015;102:1506-1516.

11. Ten Broek RPG, Stommel MWJ, Strik C, et al. Benefits and harms of adhesion barriers for abdominal surgery: a systematic review and meta-analysis. Lancet. 2014;383:48-59.

12. Sikirica V, Bapat B, Candrilli SD, Davis KL, Wilson M, Johns A. The inpatient burden of abdominal and gynecological adhesiolysis in the US. BMC Surg. 2011;11:13.

13. Jansen RP. Controlled clinical approaches to investigating the prevention of peritoneal adhesions. Prog Clin Biol Res. 1990;358:177-192.

14. Pados G, Venetis CA, Almaloglou K, Tarlatzis BC. Prevention of intra-peritoneal adhesions in gynaecological surgery: theory and evidence. Reprod Biomed Online. 2010;21:290-303.

15. Ouaissi M, Gaujoux S, Veyrie N, et al. Post-operative adhesions after digestive surgery: their incidence and prevention: review of the literature. J Visc Surg. 2012;149:e104-114.

16. Menzies D, Ellis $H$. Intestinal obstruction from adhesions-how big is the problem? Ann R Coll Surg Engl. 1990;72:60-63.

17. Butureanu SA, Butureanu TA. Pathophysiology of adhesions. Chirurgia (Bucur). 2014;109:293-298.

18. Honjo K, Munakata S, Tashiro Y, et al. Plasminogen activator inhibitor-1 regulates macrophage-dependent postoperative adhesion by enhancing EGF-HER1 signaling in mice. FASEB J. 2017;31:2625-2637.

19. Saed GM, Diamond MP. Differential expression of alpha smooth muscle cell actin in human fibroblasts isolated from intraperitoneal adhesions and normal peritoneal tissues. Fertil Steril. 2004;82:1188-1192.

20. Tomasek JJ, Gabbiani G, Hinz B, Chaponnier C, Brown RA. Myofibroblasts and mechano-regulation of connective tissue remodelling. Nat Rev Mol Cell Biol. 2002;3:349-363.

21. Roberts AB, Sporn MB, Assoian RK, et al. Transforming growth factor type beta: rapid induction of fibrosis and angiogenesis in vivo and stimulation of collagen formation in vitro. Proc Natl Acad Sci U S A. 1986;83:4167-4171. 
22. Ignotz RA, Massague J. Transforming growth factor-beta stimulates the expression of fibronectin and collagen and their incorporation into the extracellular matrix. J Biol Chem. 1986;261:4337-4345.

23. Ignotz RA, Endo T, Massague J. Regulation of fibronectin and type I collagen mRNA levels by transforming growth factorbeta. J Biol Chem. 1987;262:6443-6446.

24. Biernacka A, Dobaczewski M, Frangogiannis NG. TGF-beta signaling in fibrosis. Growth Factors. 2011;29:196-202.

25. Chen Y, Yang S, Peng Y, Yang Z. The regulatory role of IL-6R in hepatitis B-associated fibrosis and cirrhosis. Braz J Med Biol Res. 2017;50:e6246.

26. Jin X, Zimmers TA, Perez EA, Pierce RH, Zhang Z, Koniaris LG. Paradoxical effects of short- and long-term interleukin-6 exposure on liver injury and repair. Hepatology. 2006;43:474-484.

27. Jin $X$, Zhang Z, Beer-Stolz D, Zimmers TA. Koniaris LG Interleukin-6 inhibits oxidative injury and necrosis after extreme liver resection. Hepatology. 2007;46:802-812.

28. Cheong YC, Shelton JB, Laird SM, et al. IL-1, IL-6 and TNFalpha concentrations in the peritoneal fluid of women with pelvic adhesions. Hum Reprod. 2002;17:69-75.

29. Chegini N, Kotseos K, Zhao Y, et al. Differential expression of TGF-beta1 and TGF-beta3 in serosal tissues of human intraperitoneal organs and peritoneal adhesions. Hum Reprod. 2001;16:1291-1300.

30. Falk P, Bergstrom M, Palmgren I, Holmdahl L, Breimer ME, Ivarsson ML. Studies of TGF-beta(1-3) in serosal fluid during abdominal surgery and their effect on in vitro human mesothelial cell proliferation. J Surg Res. 2009;154:312-316.

31. Cheng Y, Zhang G, Li G. Targeting MAPK pathway in melanoma therapy. Cancer Metastasis Rev. 2013;32:567-584.

32. Jin X, Ren S, Macarak E, Rosenbloom J. Pathobiological mechanisms of peritoneal adhesions: the mesenchymal transition of rat peritoneal mesothelial cells induced by TGF-beta1 and IL- 6 requires activation of Erk1/2 and Smad2 linker region phosphorylation. Matrix Biol. 2016;51:55-64.

33. Femel J, Huijbers EJ, Saupe F, et al. Therapeutic vaccination against fibronectin ED-A attenuates progression of metastatic breast cancer. Oncotarget. 2014;5:12418-12427.

34. Liu Q, Zhang Y, Mao H, et al. A crosstalk between the Smad and JNK signaling in the TGF-beta-induced epithelialmesenchymal transition in rat peritoneal mesothelial cells. PLoS One. 2012;7:e32009.

35. Panahi F, Sadraie SH, Khoshmohabat H, Shahram E, Kaka G, Hosseinalipour M. Macroscopic and pathological assessment of methylene blue and normal saline on postoperative adhesion formation in a rat cecum model. Int J Surg. 2012;10:537-541.

36. Postlethwaite AE, Shigemitsu H, Kanangat S. Cellular origins of fibroblasts: possible implications for organ fibrosis in systemic sclerosis. Curr Opin Rheumatol. 2004; 16:733-738.

37. Bellini A, Mattoli S. The role of the fibrocyte, a bone marrowderived mesenchymal progenitor, in reactive and reparative fibroses. Lab Invest. 2007;87:858-870.

38. Kamato D, Burch ML, Piva TJ, et al. Transforming growth factor-beta signalling: role and consequences of Smad linker region phosphorylation. Cell Signal. 2013;25:2017-2024.

39. Wermuth PJ, Del Galdo F, Jimenez SA. Induction of the expression of profibrotic cytokines and growth factors in normal human peripheral blood monocytes by gadolinium contrast agents. Arthritis Rheum. 2009;60:1508-1518.

40. Mendoza FA, Piera-Velazquez S, Farber JL, Feghali-Bostwick C, Jimenez SA. Endothelial cells expressing endothelial and mesenchymal cell gene products in lung tissue from patients with systemic sclerosis-associated interstitial lung disease. Arthritis Rheum. 2016;68:210-217.

41. Thiery JP, Sleeman JP. Complex networks orchestrate epithelial-mesenchymal transitions. Nat Rev Mol Cell Biol. 2006; 7:131-142.

42. Thiery JP, Acloque H, Huang RY, Nieto MA. Epithelialmesenchymal transitions in development and disease. Cell. 2009;139:871-890.

43. Kalluri R, Neilson EG. Epithelial-mesenchymal transition and its implications for fibrosis. J Clin Invest. 2003;112:1776-1784.

44. Duscher D, Maan ZN, Wong VW, et al. Mechanotransduction and fibrosis. J Biomech. 2014;47:1997-2005.

45. Wipff PJ, Rifkin DB, Meister JJ, Hinz B. Myofibroblast contraction activates latent TGF-beta1 from the extracellular matrix. J Cell Biol. 2007;179:1311-1323.

46. Shinde AV, Humeres C, Frangogiannis NG. The role of alphasmooth muscle actin in fibroblast-mediated matrix contraction and remodeling. Biochim Biophys Acta. 2017;1863:298-309.

47. Wang J, Wang L, Xu L, et al. Targeting Src attenuates peritoneal fibrosis and inhibits the epithelial to mesenchymal transition. Oncotarget. 2017;8:83872-83889.

48. Hinz B. The role of myofibroblasts in wound healing. Curr Res Transl Med. 2016;64:171-177.

49. Lua I, Li Y, Pappoe LS, Asahina K. Myofibroblastic conversion and regeneration of mesothelial cells in peritoneal and liver fibrosis. Am J Pathol. 2015;185:3258-3273.

50. Li Y, Wang J, Asahina K. Mesothelial cells give rise to hepatic stellate cells and myofibroblasts via mesothelialmesenchymal transition in liver injury. Proc Natl Acad Sci U S A. 2013;110:2324-2329.

51. Bhattacharyya S, Wei J, Varga J. Understanding fibrosis in systemic sclerosis: shifting paradigms, emerging opportunities. Nat Rev Rheumatol. 2011;8:42-54.

52. Habiel DM, Hogaboam CM. Heterogeneity of fibroblasts and myofibroblasts in pulmonary fibrosis. Curr Pathobiol Rep. 2017;5:101-110.

53. El Agha E, Kramann R, Schneider RK, et al. Mesenchymal stem cells in fibrotic disease. Cell Stem Cell. 2017;21:166-177.

54. Cheng H, Terai M, Kageyama K, et al. Paracrine effect of NRG1 and HGF drives resistance to MEK inhibitors in metastatic uveal melanoma. Cancer Res. 2015;75:2737-2748.

55. Hong WX, Hu MS, Esquivel M, et al. The role of hypoxiainducible factor in wound healing. Adv Wound Care. 2014;3:390-399.

56. Chen MJ, Chen TY, Cheng YM, Hsu YC. The effect of postoperative hyperbaric oxygen treatment on intraabdominal adhesions in rats. Int J Mol Sci. 2012;13:12224-12231.

57. Hitraya EG, Varga J, Artlett CM, Jimenez SA. Identification of elements in the promoter region of the alpha1(I) procollagen gene involved in its up-regulated expression in systemic sclerosis. Arthritis Rheum. 1998;41:2048-2058.

58. Kohan M, Muro AF, White ES, Berkman N. EDA-containing cellular fibronectin induces fibroblast differentiation through binding to alpha4beta7 integrin receptor and MAPK/Erk 1/2dependent signaling. FASEB J. 2010;24:4503-4512. 